$2019,20(1)$, pp. $70-79$, DOI: $10.18038 /$ aubtda. 459191

\title{
EFFECT OF FREQUENCY CONTENT ON THE DYNAMIC PROPERTIES OF THE SAND
}

\author{
Ersin GÜLER ${ }^{1}$, Kamil Bekir AFACAN 2,*
}

${ }^{1}$ Construction Technology, Sivrihisar Vocational School of Higher Education, Eskişehir Osmangazi University, Eskişehir,Turkey
${ }^{2}$ Department of Civil Engineering, Faculty of Engineering and Architecture, Eskişehir Osmangazi University, Eskişehir, Turkey

\begin{abstract}
Under repeated loads, stress-strain and strength properties of soils play an important role in solving the engineering problems. The resistance of a material is defined by the slope of the initial part of stress-strain curve. However, this value changes due to cyclic loading and decreases cycle by cycle. As a result, deformations occur on the ground and resulting structural damage. Engineering properties of soils (such as modulus and damping properties of soil, shear wave velocity, unit weight etc..) must be known to minimize the effects of earthquakes. Another important parameter is the frequency content of earthquakes which directly affects the wave propagation through the soil. In this study, the effects of frequencies, obtained from different earthquakes, on the dynamic characteristics of the soil have been investigated. A dynamic triaxial test set has been used to examine the dynamic properties of soils. The variation of dynamic properties of sand samples under the experimental conditions has been determined for regular and irregular loading types.
\end{abstract}

Keywords: Cyclic triaxial test, frequency, Normalized shear modulus, Damping ratio, Shear deformation

\section{INTRODUCTION}

Soils are subjected to large deformations due to repeated loads. One of the most important these repetitive loads is the earthquakes which are of great importance for geotechnical engineers. The behavior of soils resulting from the stresses caused by the earthquakes is very different compare to the ones from the stresses caused by static loads. For this reason, the predictions of seismic loads which the structure is exposed will be more realistic considering the stress-strain characteristics of the soils under cyclic loads, i.e. their dynamic properties.

The dynamic behavior of the soil at different levels of deformation is defined by two fundamental relationships: 1) the change of the normalized shear modulus at increasing strain level, and 2) the change of the damping ratio for different strains. These relationships, which have been largely studied in the literature, are usually found by either stress-controlled or strain-controlled tests in the laboratory or in the field under harmonic loading. Generally, the frequency of the load is kept constant and accepted as $1 \mathrm{~Hz}$ in most of the studies i.e. Darendeli (2001) [1].

The shear stresses generated by the earthquakes are irregular in terms of both amplitude and frequency due to the change of the behavior during the transmission of the shear waves through the soil column from the base to the ground [2]. Therefore, it is clear that using a constant frequency value to estimate the dynamic properties of soil will result altering the behavior of the ground differently. For this reason, the effect of the frequency content from different earthquakes should be investigated in order to evaluate the stress-strain behavior of soils under different cyclic loads, to compare the behavior change for different frequencies, and finally to obtain the realistic loads which the structures will be subjected.

The stress conditions of soils during the earthquakes can generally be simulated in the laboratory using the dynamic test systems such as dynamic triaxial test, resonant column test and they are widely used in the literature to study the dynamic properties of sand $[3,4,5]$.

*Corresponding Author: kafacan@ogu.edu.tr

Received: 11.09.2018 Accepted: 17.01.2019 
In this study, the dynamic triaxial test system at the Eskisehir Osmangazi University Soil Mechanics Laboratory was used to understand the effect of the different frequencies on cyclic behavior of sandy soils. The effect of the frequencies on the modulus reduction curve and damping ratios of the sandy soils was examined and compared with the behavior under regular (harmonic) loading.

\section{SOIL BEHAVIOR UNDER CYCLIC LOADING}

Dynamic loads can be grouped into earthquakes, explosions underground or vibrations caused by vibrating machines such as machines or trains. Earthquakes causing the biggest deformations can be defined as the shaking of the places as passing in waves through soil resulting from the vibrations that occur as an outcome of breaking in the earth's crust [6]. Velocity and displacement time series can be calculated by using acceleration records of earthquakes. The dimension of the acceleration is expressed in $\mathrm{g}$ whereas the displacement level in $\mathrm{m}$ to be able to present the dimensions of the resulting movement. Figure 1 shows the time-series of acceleration and velocity and displacement records of the 1999 Kocaeli Earthquake. The record was taken from the Pacific Earthquake Engineering Research Center (PEER) and the station number is recognized as 1165 by PEER.

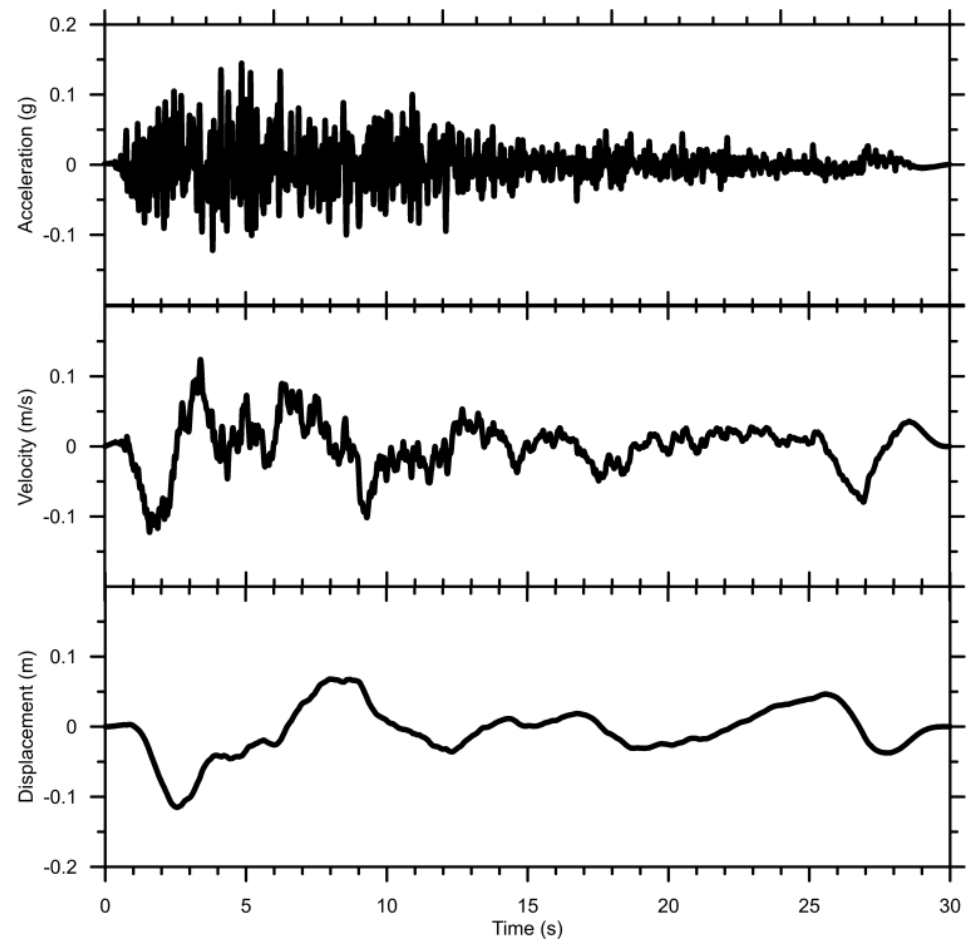

Figure 1. a) Acceleration b) Velocity c) Displacement time series

In order to reduce the damages caused by the earthquakes, the engineering properties of the ground response in other words the excitation that the structure above is exposed must be carefully evaluated. This can only be possible by understanding of the soil dynamic properties. The magnitude, the peak ground acceleration (PGA), velocity (PGV) and displacements (PGD), frequency contents, durations of earthquakes are some important parameters that should be known to estimate the soil behavior [7].

Earthquakes are very complex excitations due to irregularity that consist of a wide frequency range. The frequency of the earthquake determines the shape of the waves how it will be transmitted through the soil. For this reason, the characteristics of a motion must be defined by considering the frequency content of that specific earthquake. Any periodic function can be expressed by Fourier transform. The Fourier transform is can be described as the sum of the series of simple harmonic motions in different frequencies, amplitudes and phases. The equation form of the transform is shown below. [8]. 


$$
x(t)=c_{0}+\sum_{n=1}^{\infty} c_{n} \sin \left(\varpi_{n} t+\varphi_{n}\right)
$$

In the equation, $\mathrm{c}$ values are the amplitudes, $\varphi$ values are the phase angles (shifts on the $\mathrm{x}$ axis) and $\omega$ values represent the frequencies.

The Fourier amplitude spectrum of a strong ground motion shows how the motion amplitude is distributed over the frequency. Therefore, it may be useful in determining what frequency components the excitation is formed of and which component is higher, so that the dominant frequency of the motion can be estimated. Figure 2 shows the Fourier amplitude of the 1999 Kocaeli earthquake using the acceleration time series. The point at which the largest value of the Fourier amplitude is defined as the predominant frequency. For the record shown in Figure 2, this value is calculated as $f_{p}=7.62 \mathrm{~Hz}$ and the corresponding predominant period is about $0.13 \mathrm{sec}$.

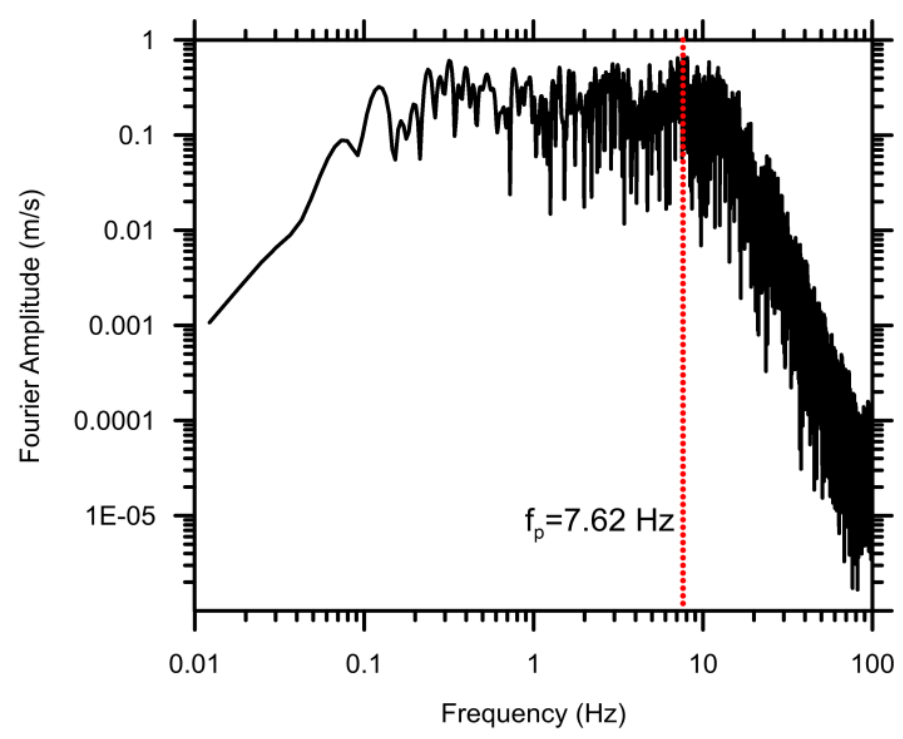

Figure 2. Fourier amplitude of acceleration record of Kocaeli earthquake

The behavior of soils under dynamic loads is studied in two groups. The first approach models the stressstrain relations and the second one models the degradation of strength of the soil by cycles. From the stress-strain data obtained from the laboratory experiments, the dynamic shear modulus, the damping ratio and the change of these values depending on the shear strain are generally gathered to understand the nonlinearity of soil behavior. For the other approach, the decrease of shear stress amplitude over cycles is the main focus [9].

The stress-strain relation of the soils observed from the laboratory experiments is generally represented by hysteresis curves as shown in Fig.3. The parameters seen on the figure should be known so that the behavior of the soil under repeated loads can be examined.

Shear modulus G, one of the most important characteristics of soils, is expressed as the slope of the curve passing through the end points of hysteresis for different loops. The shear stresses passing through the end points of the hysteresis curve is the curvilinear function of the shear strain and the maximum dynamic shear modulus $\mathrm{G}_{\max }$ is expressed as the slope of the end points of the initial hysteresis loop recorded in very small shear strain [10]. 


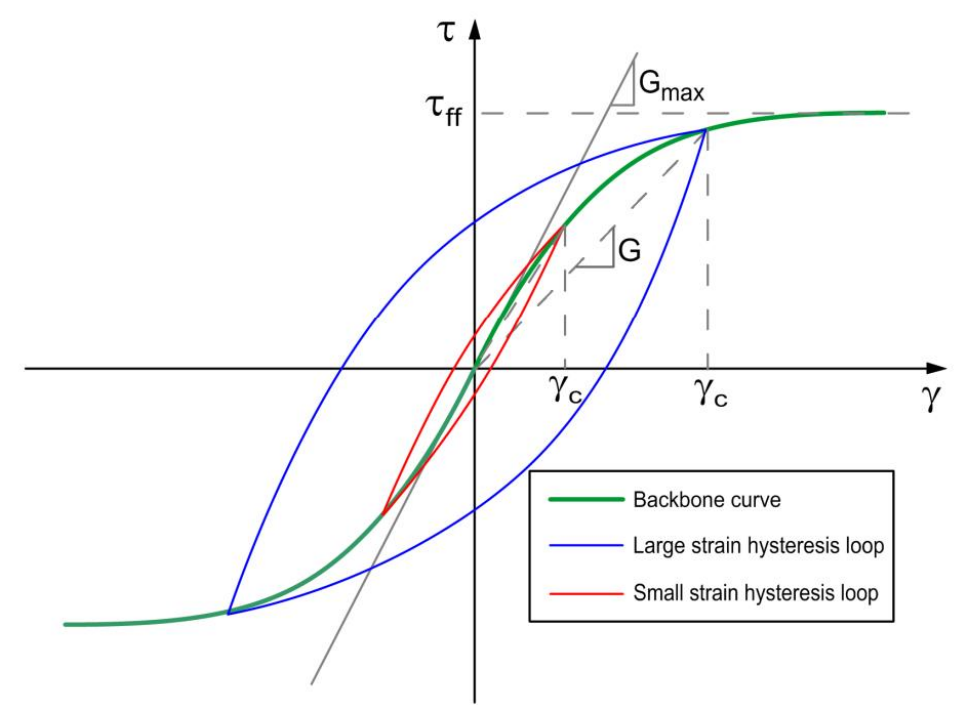

Figure 3. An example stress-strain curve and its characteristics taken from Stewart et al. [10].

The dynamic shear modulus of the soils is defined as the slope of shear stress-strain loop and is calculated by the expression shown in equation 1 . The backbone curve of soil is described as the curve where the end points of the loops meet. This curve is important when estimating the shear stress at any level of strain.

$$
G=\frac{\tau}{\gamma}
$$

As explained above, $G_{\max }$ defines the maximum rigidity of the soil and can only be obtained at very small strains (i.e. $10^{-6} \sim 10^{-7} \%$ ). In the laboratory, this property is determined by the resonant column test system. Having difficulty of getting the shear modulus at these deformation levels, the shear wave velocity evaluated from the field tests can be used to calculated by the following equation, depending on the shear wave velocity and the density of the soil.

$$
G_{\max }=\rho V_{s}^{2}
$$

Every cycle of loading, soil goes under some deformation and absorbs some energy. The amount of energy dissipated after a cycle is characterized by the damping ratio. The amount of damping, $\mathrm{D}$, is calculated from the stress-strain hysteresis. This property is a key instrument when modeling wave propagation through the soil, how much energy is transmitted one layer to another and what shape and amplitude of displacement the surface of the soil gets after dynamic loads. Figure 4 shows an example cycle recorded under a dynamic loading. The average of maximum and minimum shear stresses and shear strains recorded for a specific cycle are expressed as $\tau_{\mathrm{c}}$ and $\gamma_{\mathrm{c}}$, respectively. By calculating the bolded area in the hysteresis loop, the hysteretic damping can be calculated as shown in equation 4 [11]. These two important characteristics, shear modulus and damping properties of soils, are very crucial for dynamic geotechnical engineering applications.

$$
D=\frac{1 A_{\text {loop }}}{2 \pi \cdot G_{\text {sec }} \cdot \gamma_{c}^{2}}
$$




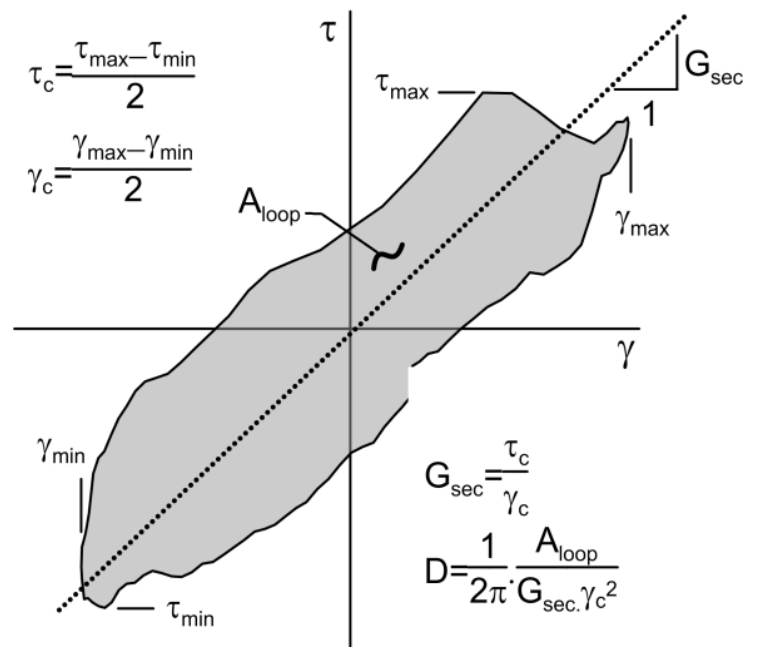

Figure 4. Schematic illustration of a stress-strain loop and the definitions of secant modulus with hysteretic damping

\section{MATERIAL AND METHOD}

Experiments in this study were carried out with the Dynamic Triaxial Test System in the Soil Mechanics Laboratory of Eskişehir Osmangazi University. The test equipment consists of servo valves that provide closed-loop, electro-hydraulic and vertical motion control. With the dynamic triaxial test system, vertical load, vertical displacement, pore water pressure and volume changes can be measured. The test system is presented in Figure 5.

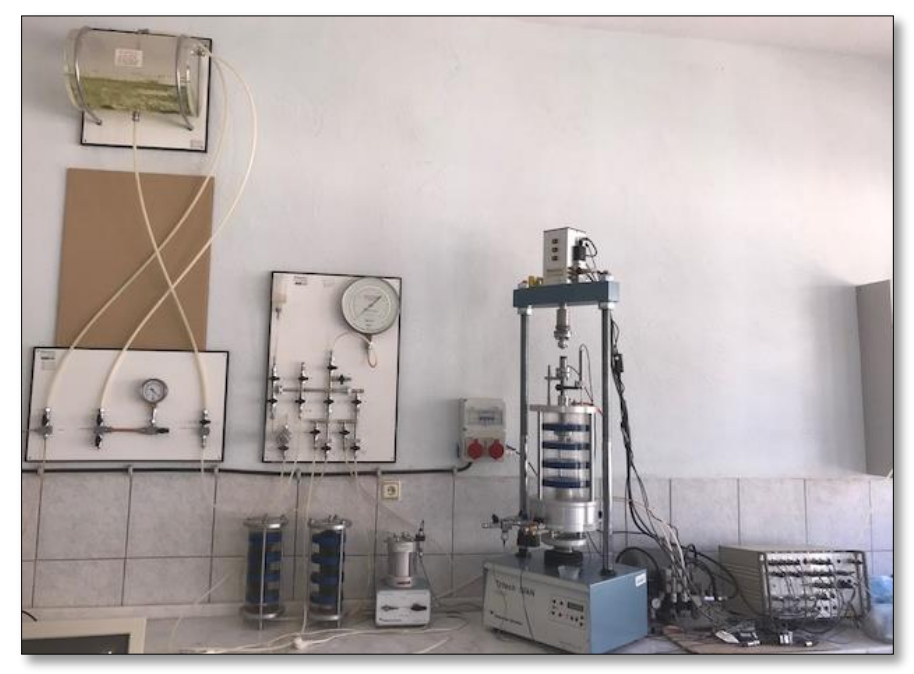

Figure 5. Dynamic triaxial test system

\subsection{Sample properties and loading types}

The sand used in this study is the standard Podima sand which is standard testing sand locally obtained from Çanakkale. It is a uniform, fine-grained, rounded sand and it has light brown color. The properties of the soil sample are shown in Table 1. 
Table 1. Soil index properties

\begin{tabular}{lr}
\hline Classification & $\mathrm{SP}$ \\
$\mathrm{G}_{\mathrm{s}}$ & 2,63 \\
$\rho_{\mathrm{d}, \min }$ & $1,56 \mathrm{gr} / \mathrm{cm}^{3}$ \\
$\rho_{\mathrm{d}, \max }$ & $1,80 \mathrm{gr} / \mathrm{cm}^{3}$ \\
\hline
\end{tabular}

According to the Unified Soil Classification System (USCS), the material used in the experiment is classified as the poorly graded sand (SP) and the grain size distribution is seen in Figure $6 . \mathrm{D}_{60}, \mathrm{D}_{30}$ and $\mathrm{D}_{10}$ were obtained from the curve as $0,91,0,51$ and 0,16 , respectively and the uniformity coefficient $\mathrm{Cu}$ and the continuity coefficient $\mathrm{Cc}$ were calculated as 5,68 and 1,79.

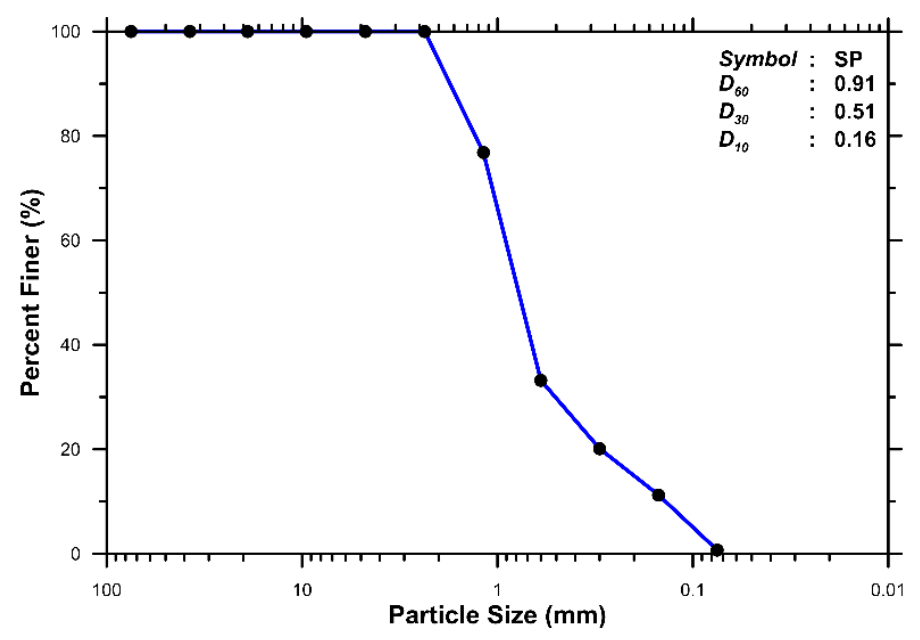

Figure 6. The grain size distribution of the Podima sand

The effects of sample preparation methods on soil behavior have been investigated in the literature a lot and most preferred techniques are dry vibration, dry tamping, wet vibration and wet tamping $[12,13$, 14]. In this study, dry tamping method was chosen to prepare samples.

The dried Podima sand was placed into a split mold which was surrounded by a membrane with the help of a funnel. The height and the diameter of the soil sample were measured as 140 and $70 \mathrm{~mm}$, respectively. The prepared specimen was placed in the form of slight vibrations by tamping and compacted to the target relative density was determined as $40 \%$. A certain amount of vacuum was applied from the top of the head until the soil specimen can stand alone without the container help. Then, the cell was filled with water by attaching the top heads required for the dynamic triaxial experiment. The drains were opened in the test system to ensure to saturate the sample. The cell pressure and back pressure were gradually increased until the cell pressure of $65 \mathrm{kPa}$ after saturation of the sample. The sample was consolidated for a short time then it was excited by different type of loads. Finally, the stress-strain relationships were recorded for different tests to understand the frequency effect.

In a series of tests, six equivalent samples were loaded by a regular type of load (harmonic sine wave) and irregular loads with different frequency contents. The shapes of irregular loading types were derived from real earthquake records. Stress-controlled experiments were performed and the applied axial stress versus time series are shown in Figure 7. The amplitudes for each different loads were kept constant (50 $\mathrm{kPa}$ of peak to peak) but the frequency content varied due to the shape of the loading. The harmonic sine loading was also placed in each figure for all the types of loading to be able to compare the regular and irregular loading types. 


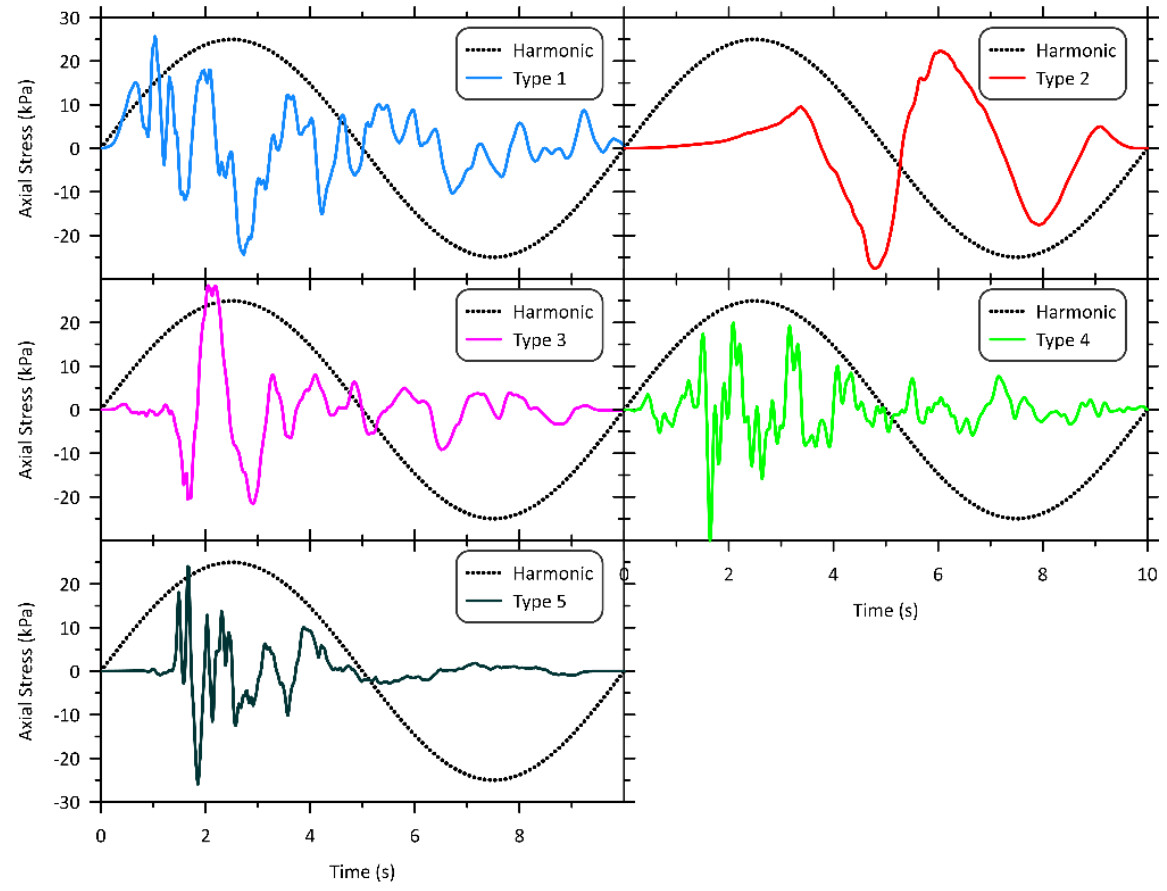

Figure 7. Axial stress-time series for different type of loads

Then, the Fourier amplitudes were calculated for different loading types, the peak values were determined and they both are shown in Figure 8. In terms of predominant frequencies, the Fourier amplitude is highest for the Type 5 and lowest for the Type 1 . The predominant frequency range varies from $0.23 \mathrm{~Hz}$ to 1.18 for 5 different loads, whereas the corresponding amplitudes vary from about 10 to $60 \mathrm{kPa}$-s. In literature, this frequency value is generally assumed as $1 \mathrm{~Hz}$ in calculating the dynamic properties of soils. The purpose here was to have variety of pre-dominant frequencies and see if they affect the modulus and damping properties of soil.

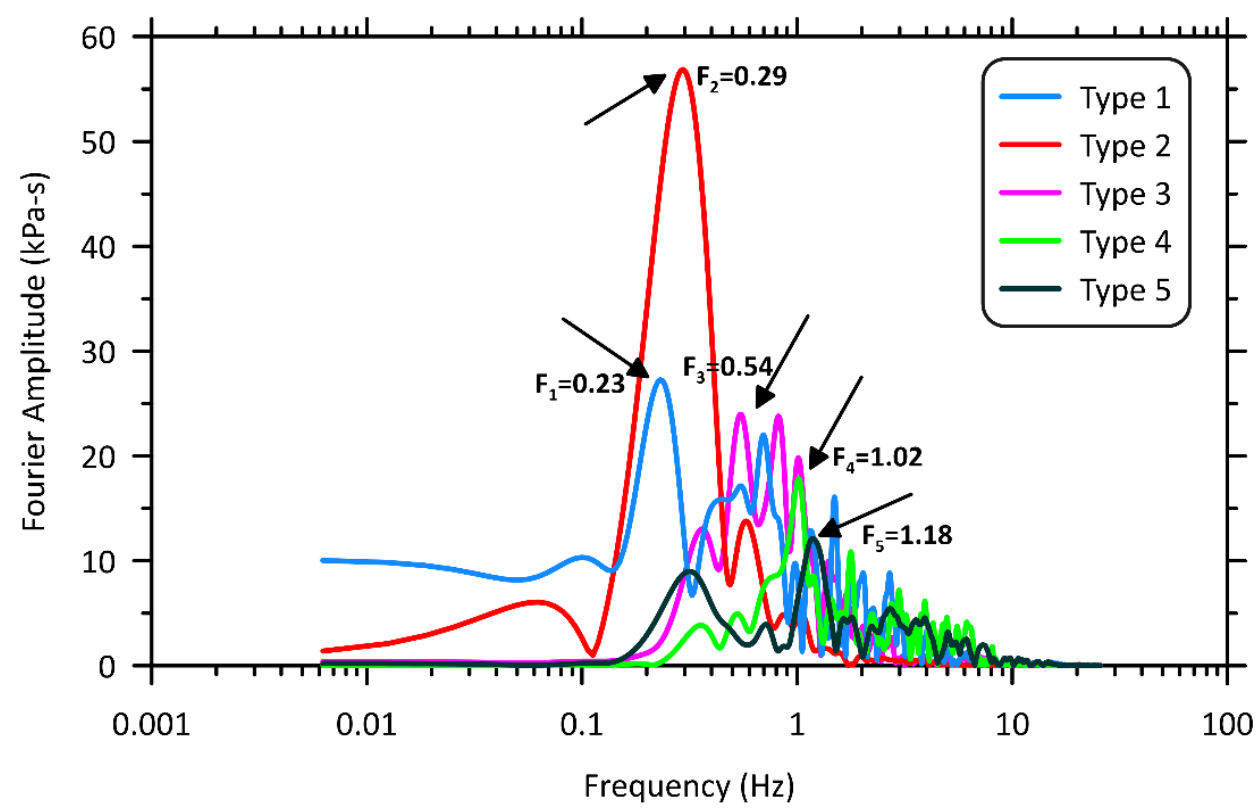

Figure 8. Fourier amplitudes of different type of loadings 


\section{RESULTS}

In this study, the effects of regular and irregular loading types and their corresponding frequencies on the dynamic behavior of Podima sand were investigated. The stress strain loops recorded from the tests were extracted and shear modulus and damping ratios for each loop were calculated. The differences of the normalized shear modulus values at different shear strain levels for all loading types are shown in Fig.9. In terms of the variation due to the frequency effect, it is seen that the normalized shear modulus curves shifted below for the Type 4 and Type 5 loads with a dominant frequency greater than 1 . For other irregular types of loads whose dominant frequencies are less than $0.6 \mathrm{~Hz}$, the normalized modulus reduction curves follow the similar path with the normalized shear modulus curve of the harmonic sine loading. Given the maximum Fourier amplitudes of the frequencies, it is observed that the Type 4 and Type 5 loads lose their strength more easily with steeper slopes. In addition, other type of loads with a dominant frequency less than $0.6 \mathrm{~Hz}$, the curves almost fall into the curve of the harmonic loading until the threshold strain $(\gamma=0.1 \% \sim 0.2 \%)$ defined by Vucetic et al. (1999). Moreover, the loss of the strength is the slowest for the type of load with the predominant frequency of $0.23 \mathrm{~Hz}$ compared to the others. In other words, the soil has more rigidity at any strain levels greater than $0.3 \%$ when it is excited by a loading with a smaller frequency compared to others.

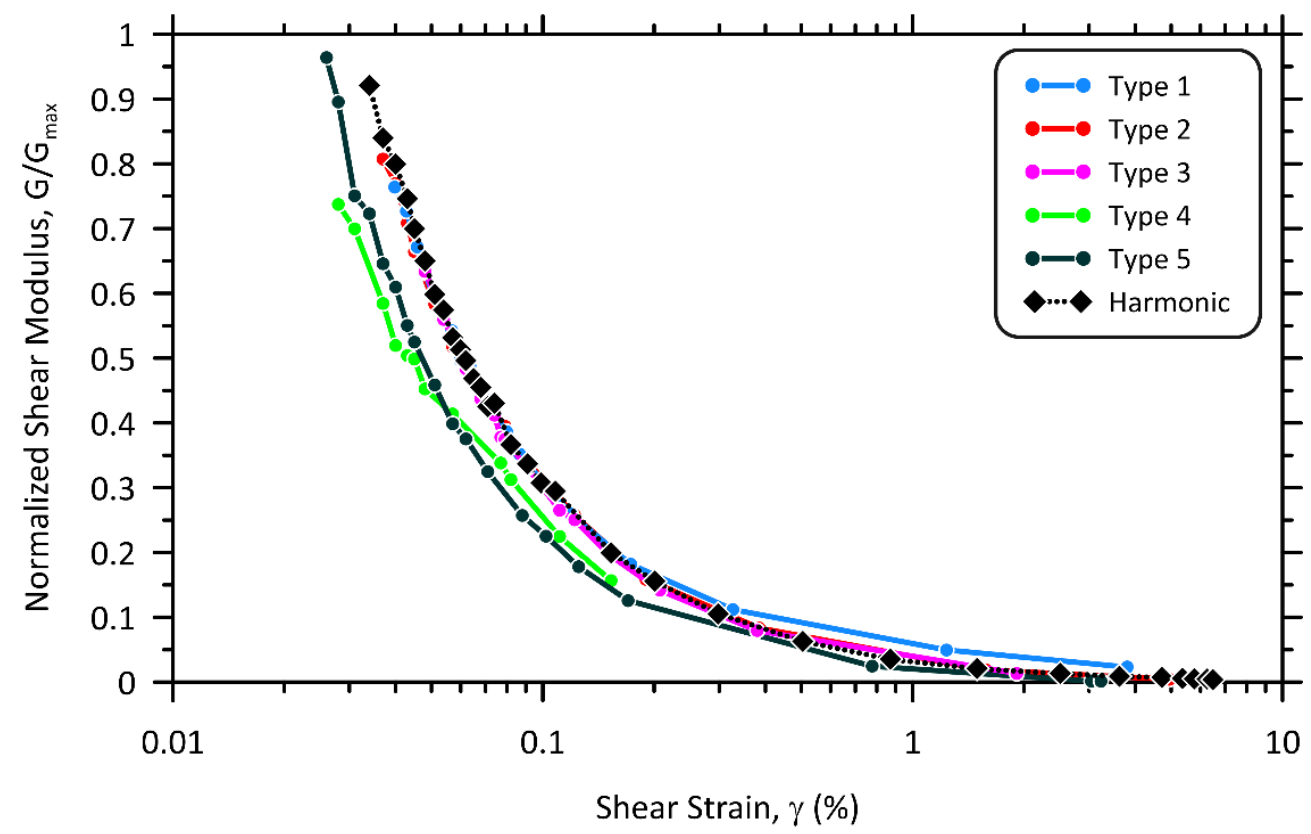

Figure 9. The normalized shear modulus-shear strain values of the frequencies used in the analyzes

In addition to the normalized shear modulus versus shear strain behavior of soil in the dynamic triaxial test, the change of the damping ratio with respect to the shear strain was also examined and is shown in Fig.10. It was determined that the damping ratios obtained from the hysteresis loops under regular and irregular loadings exhibit similar behavior in the so-called elastic region until the threshold strain value. It is also seen that they are close enough to each other for such different type of loads. As the shear strain level increases, the damping ratios for the loading Type 3 (the predominant frequency of 0.54) become the highest compared to other ones. At almost all levels of shear strain (except two points) passed beyond threshold level, the damping ratios of harmonic loading were found to be lower than other irregular type of loads. Since data is a very scattered all over, it is hard to get a damping ratio curve for other loads like the curve for the harmonic load. Moreover, it is hard to note that the frequency content directly affects the damping due to complexity of the scattered data. 


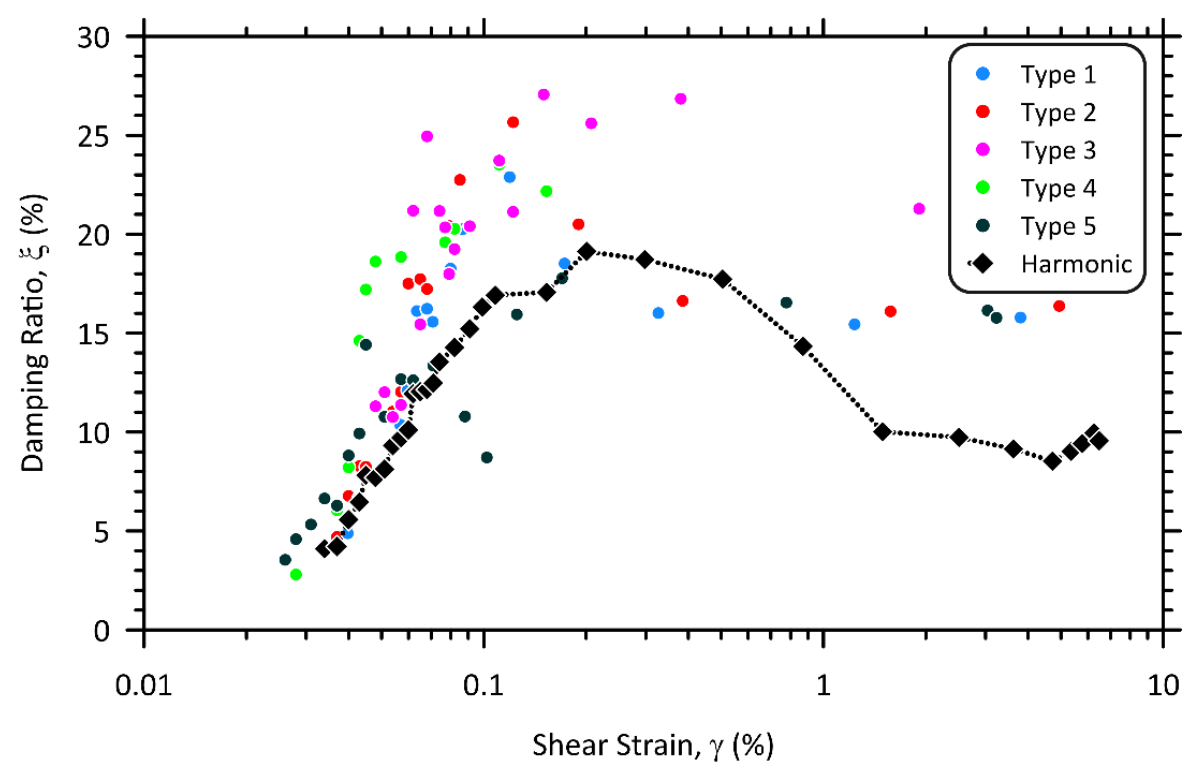

Figure 10. The damping ratio of the frequencies used in the analyzes-the strain values

\section{CONCLUSION}

Determination of the dynamic properties of the soils is an important issue for geotechnical engineers to be able to establish the response on the ground realistically that the structure will be affected. In this study, the effects of frequency content on the dynamic behavior of soils under regular and irregular loads with different predominant frequencies were investigated by using the dynamic triaxial experiment system. Six dynamic triaxial experiments were carried out under a harmonic load and irregular loads obtained from different earthquakes. The Fourier amplitudes of the loads and their corresponding predominant frequencies were calculated. Normalized shear modulus-shear strain curves and damping ratios at different shear strain levels were obtained for 6 different loading types and the variations with frequency were presented in Figure 9 and Figure 10.

The following points are observed as a result of the analyses:

- In terms of modulus reduction curves, the ones evaluated from the load types with predominant frequencies greater than $1.0 \mathrm{~Hz}$ have sharper slopes compared to the others with lower frequency values, resulting in easier loss of strength. It has been also found that the curves calculated from the loading Type 4 and Type 5 group together and have similar curvature whereas the other curves observed from the loading types with lower predominant frequencies act together showing almost exact behavior as the curve resulted from the harmonic loading.

- Another point is that the damping ratios calculated from the hysteretic loops for different types of loads with different frequency contents are close to each other in regions where the shear strain is in the elastic zone being smaller than $0.1 \%$ but when it passes this region the data scatters all over. As the shear strain level increases, the energy damped from the irregular type of loadings are more than the energy absorbed from the harmonic loading type.

- Although the Podima sand samples were conducted with the loads with the same peak-to-peak amplitude, the effect of the frequency content is crucial when calculating the resistance of the soil for varying shear strains. Assuming frequency constant and $1 \mathrm{~Hz}$ to estimate the normalized shear modulus curve for a sandy soil as the studies in the literature propose disregards the shift of the curves due to variation of the frequency content. However, regarding the damping ratios, the frequency content of different type of loadings may not be a direct effect on the behavior over the elastic region that the shear strain is bigger than $0.1 \%$ or at least it is hard to tell with the data presented here. The energy to be able to finish a loop before the threshold strain for 
Güler and Afacan / Eskişehir Technical Univ. J. of Sci. and Tech. A-Appl. Sci. and Eng. 20 (1) - 2019

different type of loadings is similar whereas it differs a lot over the threshold strain zone spreading the data over a wide range.

\section{REFERENCES}

[1] Darendeli MB. Development of a new family of normalized modulus reduction and material damping curves. PhD, Univ. of Texas at Austin, Austin, 2001.

[2] Afacan KB, Vd. Düzenli ve Düzensiz Tekrarlı Yükler Altında Kum Zeminlerin Dinamik Davranışı., 4.Uluslararası Deprem Mühendisliği ve Sismolojisi Konferansı; 11-13 Ekim Eskişehir.(in Turkish) 2017.

[3] Onur Mİ, Umu SU, Okur DV, Tuncan M. An Approach to Determine the Initial Shear Modulus of Clean Sandy Soils, Global Journal of Researches in Engineering: E Civil And Structural Engineering, 2017, p 31-39.

[4] Umu SU, Onur Mİ, Okur DV, Tuncan M, Tuncan A. Reliability Evaluation of Dynamiz Characteristics of Clean Sand Soils Based on Soft Computing Methods, Arabian Journal for Science and Engineering, 2016, p 1363-1373.

[5] Ural N, Önalp A. Dinamik Üç Eksenli Kesme Deneyinin Monterey Kumu İle Kalibrasyonu, Deprem Sempozyumu, 23-25 Mart Kocaeli. 2005.

[6] Güler E, Yılmaz G, Bozbey İ. Şevlerin Performansının Dinamik Yükler Altında İncelenmesi. 4.Uluslararası Deprem Mühendisliği ve Sismolojisi Konferans1; 11-13 Ekim Eskişehir. (in Turkish) 2017.

[7] Özkan Y. Zemin Dinamiğine Giriş, Ankara, Türkiye, Nobel Yayıncılık, (in Turkish) 2017.

[8] Mokhberioskouei L. 23 Ekim 2011 ve 09 Kasım 2011 Tarihli Van Depremlerinin Kuvvetli Yer Hareketlerinin, Yeni Nesil Azalım İlişkileri İle Karşılaştırılması., İstanbul Teknik Üniversitesi, İstanbul. (in Turkish) 2014.

[9] Altun S. Suya Doygun Kumların Drenajsız Koşullardaki Davranışının Tekrarlı Yükler Altında Burulmalı Kesme Deney Aleti İle İncelenmesi, DEÜ Mühendislik Fakültesi Fen ve Mühendislik Dergisi, İzmir (in Turkish) 2004, p. 139-152.

[10] Stewart JP, Afshari K and Hashash YMA. Guidelines for performing hazard-consistent onedimensional ground response analysis for ground motion prediction. Report PEER 2014-16, Pacific Earthquake Engineering Research Center, 2014; 152 p.

[11] Afacan KB, Brandenberg SJ, Stewart JP. Centrifuge modeling studies of site response in soft clay over wide strain range [ASCE]. J Geotech Geoenviron Eng 2014;140(2):04013003.

[12] Yoshimi Y, Tokimatsu K, Ohara J. In situ liquefaction resistance of clean sands over a wide density range. Geotechnique. 1994; 44(3): 479-94.

[13] Vaid YP, Sivathayalan S, Stedman D. Influence of Specimen-Reconstituting Method on the Undrained Response of Sand., Geotechnical Testing Journal. 1999; 22(3): 187-195.

[14] Wood FM, Yamamuro JA, Lade PV. Effect of depositional method on the undrained responese of silty sand., Canadian Geotechnical Journal 2008; 45: 1525-1537. 